\title{
ON CONCEPTUAL APPROACHES TO DEVELOPING THE EAEU COMMON FINANCIAL MARKET
}
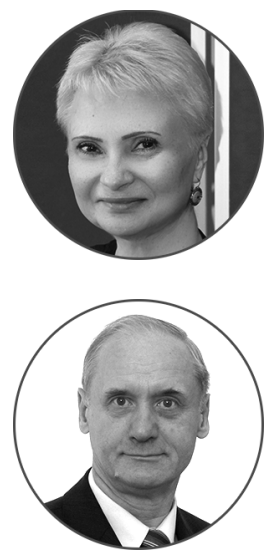

Article history:

Received 25 October 2017

Received in revised form

8 November 2017

Accepted 22 November 2017

Translated 13 March 2018

Available online 27 March 2018

JEL classification: E31, E44, F36, F45, F52

Keywords: financial market, banking services market, securities market, insurance market, financial stability, institutional structure

\section{Elena A.ZVONOVA}

Financial University under Government of Russian Federation, Moscow, Russian Federation zvonovaelena7@mail.ru orcid.org/0000-0002-8923-860X

\section{Corresponding author}

\section{Viktor Ya. PISHCHIK}

Financial University under Government of Russian Federation, Moscow, Russian Federation pv915@mail.ru orcid.org/0000-0002-9013-7670

\begin{abstract}
Importance This paper considers the development of Eurasian economic integration after the creation of the Common Economic Space.

Objectives The article aims to develop conceptual approaches to the formation of EAEU common financial market. Methods In this work, the methods of comparative and statistical analysis are used. The article explores the features of the EAEU members' national financial markets.

Results The article highlights and analyzes the criteria, goals, objectives, principles and expected stages of common financial market construction and substantiates methodological approaches to the creation of the common financial market of the EAEC countries. As well, the article presents a classification of financial instability risks in the EAEU.

Conclusions and Relevance The article concludes that the principles, structure and content of the measures of the concept of formation of common financial market of the EAEU Member States should be based on the model of evolutionary progressive development of the process of integration of the financial markets of the participating countries, taking into account the peculiarities of national economies and financial systems. The results of the research can find practical application in the activities of the Eurasian Economic Commission, as well as the ministries of finance and central banks of the EAEU Member States. It is proposed to establish the Eurasian Financial Stability Board and supranational supervisory authority.
\end{abstract}

The editor-in-charge of this article was Irina M. Vechkanova Authorized translation by Irina M. Vechkanova

Currently governments and central banks of the Eurasian Economic Union (EAEU) member States and the Eurasian Economic Commission are drafting

${ }^{\dagger}$ For the source article, please refer to: Звонова Е.А., Пищик В.Я О концептуальных подходах к созданию общего финансового рынка государств - членов ЕАЭС. Финансы и кредит. 2018. Т. 24. № 1. C. 5-18. URL: https://doi.org/10.24891/fc.24.1.5 the Concept for the Common Financial Market of the EAEU in accordance with the Resolution of December 26, 2016 at the session of the Supreme Eurasian Economic Council at the top level. The significance of the documents correlates with the key role of the Common Financial Market in 
the innovative development of national economies and promoting the Eurasian integration in the mid-run.

Pursuing the integrity and consistency of the Concept for Developing the EAEU common Financial Market (Concept), it is critically important to adhere to the fundamental regulatory and legislative documents adopted by the EAEU member States, consider national specifics of economic development, banking and financial systems in respective countries, effective concepts and strategies for developing their financial markets. We believe the establishment of the Common Financial Market should be critically revised so that its positive points, errors and drawbacks are taken into account.

Fundamental principles for the creation of the Common Financial Market are stipulated in the Treaty on the Eurasian Economic Union ${ }^{1}$. Enclosed in the Treaty, the Protocol on Financial Services governs areas, process, measures and timelines for harmonizing the national laws of the EAEU member States in banking, insurance and securities (stock market) for the period up to January 1, 2025.

Harmonizing the national laws of the EAEU countries may become a cornerstone for the Common Financial Market, while the balanced, sustainable and liquid financial market of the EAEU will require much more time like in the European Union as it concerns distinctions in the scope, level and structure of the national economies and financial markets of the EAEU member States.

\section{Distinctions of National Financial Markets in the EAEU}

Models of the EAEU financial markets are predominantly bank-oriented. Their institutional structure mostly features banking institutions, which constantly reduce in numbers, thus reflecting the rapid concentration of bank capital.

The EAEU financial markets has not increased but rather decreased their significance in finance of the real economy due to scarce and low liquidity seen for the recent years (Table 1 and 2).

${ }^{1}$ Treaty on the Eurasian Economic Union signed by the Presidents of the Russian Federation, Republic of Belarus and Republic of Kazakhstan (Astana. May 29, 2014). URL: http://www.consultant.ru (In Russ.); http://www.un.org/en/ga/sixth/70/docs/treaty_on_eeu.pdf
As shown in Table 1, although the EAEU banking systems do not provide substantial financing to the real economy, banks of Russia and Belarus are more active lenders than those ones from Kyrgyzstan and Kazakhstan.

Table 2 illustrates that the securities (stock) sector are poorly diversified in the EAEU financial markets, playing a different role throughout the respective economies. The stock market of Kazakhstan is relatively more developed than the other EAEU markets. In 2016, the trading volume to GDP ratio was 92.86 percent in Kazakhstan's stock exchanges KASE and ETC as compared with 27.77 percent in the Moscow Exchange (MICEX) and Saint Petersburg International Mercantile Exchange (SPIMEX). Trading volume in the Armenian and Kyrghyz stock exchanges account for even lower indicators.

\section{The Development of Methodological Approaches to Developing the EAEU Common Financial Market}

We consider it necessary to supplement the defining criteria of the Common Financial Market as provided for in the Treaty on the Eurasian Economic Union ${ }^{2}$ with the functional definition of the common financial market emphasizing its role in the re-allocation of resources among the counties for pursuing an economic growth and moving the EAEU integration forward ${ }^{3}$. Urging the countries to mutually invest in the real economy, the Common Financial Market is called to address such most important issues as a) gradual transition to the national regime and/or

\footnotetext{
${ }^{2}$ The Treaty on the Eurasian Economic Union defines the concept of the Common Financial Market as the financial market of member States, which meets such criteria as the compliance with harmonized requirements to the regulation and supervision of the financial market of the member States; mutual recognition of licenses in banking, insurance and securities as issued by official authorities in one of the member States; financial services throughout the Union without setting up an additional office as a legal entity; administrative cooperation of official authorities of the member States, including through communication. Treaty on the Eurasian Economic Union. Addendum 17, Article 3. URL: http://docs.cntd.ru/document/420205962 (In Russ.); http://www.un.org/en/ga/sixth/70/docs/treaty_on_eeu.pdf

${ }^{3}$ The Common Financial Market shall be regarded as a combination of national financial markets and international financial market of the EAEU member States, which are supposed to reallocate financial resources among them so as to ensure long-term investment in the real economy and drive innovative development of national economies, make them sustainable and promote financial and economic integration of the region.
} 
the Most Favored Nation (MFN) treatment in certain sectors of the Common Financial Market in question; b) gradual elimination of restrictions, exceptions, additional requirements and conditions imposed concurrently with commitment to applying the national treatment; c) increasing the available resources of the Common Financial Market, developing and diversifying tools for investing in the real economy of the countries [1].

Considering the difference of the national economies in terms of their development level, banking and financial systems, the Common Financial Market can be successfully established provided that some essential principles are observed:

- step-by-step evolutionary algorithm for leading the EAEU countries to the Common Financial Market;

- sensible combination of the national, intergovernmental and supranational levels of the Common Financial Market regulation;

- approaching the creating of the Common Financial Market specifically, depending on a sector of the financial market and time;

- different and individual pace of moving the EAEU economies to the Common Financial Market to the extent certain countries are prepared and intend to implement the Common Financial Market initiative;

- establishment of the supranational financial regulator, which would be able to integrate and balance interests of each party to the Common Financial Market initiative.

Based on the fundamental principles, the consistent and comprehensive approach to the Common Financial Market initiative requires the following conditions should be met:

- the Common Financial Market actors shall provide each other access to all segments of the integrated financial market, including the currency one, by providing for the national treatment and/or MFN treatment in certain sectors of the Common Financial Market;

- the Common Financial Market actors shall declare of their mutual recognition, including the introduction of the so called Eurasian passport for financial institutions, which would allow for transacting throughout the EAEU countries (like the financial services passport for the EU and EFTA countries that make up the single internal market as part of the European Economic Area comprising 31 States) ${ }^{4}$;

- appropriate macroeconomic, macroprudential and foreign exchange and financial conditions shall be created, including agreed-upon approaches to maintaining financial sustainability, standards of currency and financial regulation and control.

\section{Steps Towards the Common Financial Market and Their Substance}

As the EAEU countries evolutionize and head towards the Common Financial Market in the foreseeable future, two steps can be pointed out, with approximate timelines being determined. The first step is stipulated in the Treaty of the Eurasian Economic Union, covering the period from 2017 through 2024, while the second step may start in 2025 after the outcome of the first one are evaluated ${ }^{5}$.

The priority of the first step (2017-2024) is to harmonize some basic principles of national laws of the EAEU countries on finance, with the following interim steps of the Common Financial Market development being the most expected (before 2025):

- the EAEU shall develop the EAEU passport and extend it to the EAEU financial institutions, which is to provide them with equal business opportunities in the EAEU (like the EU finance services passport);

- the common market of banking products and services shall be created to help the EAEU banks easily access national financial markets, harmonize the legislation

\footnotetext{
${ }^{4}$ The European financial passport is a kind of license extended to financial institutions of one of the EU countries. It permits them to operate in other EU countries in compliance with rules and requirements set by the European regulators. For example, 5,476 British companies have one or several financial passports for one or several EU counties or European Economic Area, additional members of which are Iceland, Norway, Croatia and in fact Switzerland. In the countries of continental Europe, about 8,000 financial companies have passports for operation in Great Britain.

${ }^{5}$ Analytical Report, On the Situation of Eliminating Mutual Access Barriers Impeding Operations in the EAEU Domestic Market, and Exceptions and Restriction in Relation to Flow of Goods, Services, Capital and Manpower.

URL: http://eec.eaeunion.org/ru/act/integr_i_makroec/dep_makroec_pol /developDocs/Documents.pdf
} 
and regulatory policy the banking sector of the EAEU financial markets;

- the EAEU countries shall eliminate differences in requirements to residents and non-residence when they open and hold banks accounts;

- parties shall perform agreed-upon and harmonized principles for regulating and supervising actors of financial markets in the EAEU;

- official authorities of the EAEU countries shall mutually recognize licenses issued by banking and non-banking financial intermediaries;

- the EAEU banks shall be permitted to deliver their services throughout the EAEU without establishing an additional office as a legal entity [2];

- the single stock zone of the EAEU countries shall be created by allowing brokers and dealers from one State to stock exchanges of other member States [3];

- official authorities of the EAEU countries shall cooperate concerning the issues of regulating financial institutions' operating, including communications;

- the EAEU member States shall enter into the Agreement on harmonized approaches to the regulation of the legal exchange relations and adoption of liberalization measures in the EAEU Member States (The EEC Advisory Committee ratified the draft on August 9, 2017). The Agreement is supposed to ensure free cross-border movement of financial resources, form the common financial market in the member State [4]. The EAEU Financial Stability Council shall be established;

- the supranational supervisory body of the EAEU shall be established to regulate the common financial market, being assigned a number of functions and authorities [5].

Considering the importance of the first step and relevant actions, it would be reasonable to draw upon the EU experience and put considerable efforts to set up terms and procedures for extending the so called Eurasian passport allowing the EAEU financial institutions to operate in all the EAEU countries ${ }^{6}$.

\footnotetext{
${ }^{6}$ For reference: The EU experience. In May 1999, the Financial Services Action Plan (FSAP) was adopted [10]. The main purpose of FSAP
}

Bearing in mind the predominantly bank-based model for financing the EAEU economies, like in the EU, the common banking market should be created as a priority at the second step of creating the Common Financial Market in the EAEU. It shall become the underlying basis, being the most large-scale and controllable segment of the Common Financial Market ${ }^{7}$. The EAEU banks are the most well structured and leading institutional actors of the EAEU financial markets. They are easier to be collectively observed and integrated into the common trading infrastructure, accounting, clearing and payment systems [6]. The foreign exchange market of the EAEU countries, which was historically integrated, also originated from banks entering each other's stock exchanges. Non-banking financial intermediaries have been allowed to enter the EAEU integrated foreign exchange market only recently. Concurrently, at the first step, the EAEU countries form the common markets of securities and insurance, harmonizing the regulation and oversight over operations in the EAEU financial markets, declaring mutual recognition of licenses issued to banking and non-banking financial intermediaries by the EAEU official authorities, and so on.

Harmonization principles underlie the creation of the common financial market at the first step, such as:

- adoption of some common standards and rules to regulate all segments of the financial market, which would be acceptable for all the parties;

is to set up well elaborated and refined legislative framework in the European financial markets. Hence, several dozens of legislative documents were adopted in three areas, i.e. securities, banking and insurance. The practical objective of FSAP is to provide financial companies with the uniform European passport granting them equal business opportunities throughout the EU. FSAP was to be implemented within five years. In 2005, The EU released the White Paper outlining financial service policies for the 2005-2010 period. The White Paper was intended to develop the previous successful achievements and put the EU banking sector into spotlight. As a result of the partial implementation of the FSAP second stage, European credit institutions entered into the pre-crisis 2007 being became more internationalized than the U.S. and Japanese banks. After the 2008 2009 crisis, which unraveled the vulnerability of the banking sector, the EU focused on the institutional consolidation of the European financial market.

${ }^{7}$ As of the end of 2015, 3.7 trillion of debt securities were circulating in the internal market, being just a little more than 10 percent of loans obtained from the banking sector (54.4\% of GDP in 2015). URL: https://www.cbr.ru/finmarkets/files/development/onrfr_201618.pdf 
- concurrent appointment of the priority sector of the financial market to be harmonized and jointly regulated, being of systemic significance for the future integration. This is the banking sector in the EAEU. In this respect, it coincides with the EU, where the banking sector prevails in the institutional structure of the Common Financial Market as well;

- compliance with the principle for integrating sector of the national financial markets at individual pace, as soon as they are prepared to and the political decision is taken depending on domestic conditions of the national markets;

- those countries, which are interested in the Common Financial Market, shall prepare and implement the Plan for harmonizing their legislation on the creation of the Common Financial Market. As envisaged in the EU plan for developing the Common Financial Market, member States shall adhere to a gradual evolutionary approach to the harmonization process (step-by-step approach);

- modality of the harmonization process implies certain documents should be adopted at the supranational level and subsequently incorporated into the national laws ${ }^{9}$.

At the second step starting in 2025, the member States should carry out a set of actions to develop and reinforce the Common Financial Market in segments of the markets of debt and equity securities and insurance. The securities and insurance markets need to play a greater role in accumulating long-term resources in order to drive the economic development of the EAEU countries. During the period, member States build an operational model of the single insurance segment within the Common Financial Market, seeing the development of the market of cross-sector products, instruments and services, and sector of financial derivatives. The second step of the Common Financial Market development is expected to result in measures for system integration of

\footnotetext{
${ }^{8}$ Financial Services: Implementing the Framework for Financial Markets: Action Plan. Financial Services Action Plan Communication of the Commission.

URL: http://ec.europa.eu/internal_market/finances/docs/actionplan/ind ex/action_en.pdf

${ }^{9}$ For reference: While being a part of the EU, Great Britain adopted 90,000 regulations accepted in the EU, accounting for 70 percent of all the regulatory framework in Great Britain.
}

the national financial markets and mechanisms for financial regulation and oversight and inclusion of the following unifying activities into the oversight practices alongside with the harmonization process:

- creation of the common securities market and common insurance market, thereby increasing the role of the Common Financial Market in investing in the EAEU economies [7];

- simplification of the EAEU procedures for listing stocks and derivatives;

- formation of the common trading, payment, clearance and accounting infrastructure of the Common Financial Market;

- concurrently with the harmonization process, the application of some aspects of unifying regulatory and supervisory measures which ensure smooth and effective operations in the Common Financial Market and national financial markets of the EAEU countries as its constituents.

\section{Design and Consolidation of Institutional Structure for Regulation and Oversight in the Common Financial Market}

Adhering to the system approach to developing the Common Financial Market, the EAEU countries shall not overlook an important aspect of the financial integration, such as measures for building the market infrastructure of the Common Financial Market as they streamline operations in the Common Financial Market, creating such components as:

- trading, payment clearing and accounting infrastructure, common payment system;

- common stock exchange zone;

- integrated financial market with segments;

- international financial center within the EAEU [8].

What is important for the institutional consolidation of the EAEU countries is to create and develop the system of bodies charged with regulation and oversight of the Common Financial Market so as to mitigate financial stability risks in the region. In the banking sector of the EAEU Common Financial Market, financial stability risks are associated with a) high concentration of assets 
in major banks; b) low capitalization level of banks; c) inactive lending to the real economy coupled with substantial overdue loan balances in the EAEU economies as a whole; d) divergence of the EAEU banking regulation standards in terms of quality and quantity; e) insufficient and unequal use of macroprudential regulation tools in the EAEU [9].

In the securities market, financial stability risks mainly arise from the low development level of the sector in the national financial markets, scarce supply of financial products and tools, high volatility of the sector, considerable transaction and regulatory costs, lame position of stock markets in capital expenditures.

To mitigate the financial stability risk, the following measures shall be undertaken:

- enhancing the competitiveness and effectiveness of the national economies and creating equal opportunities for developing all segments of the EAEU financial markets;

- strengthening the functional role of the stock market and institutional significance of non-banking intermediaries in ensuring financial inflows to the economy;

- improving the quality of regulation and oversight in the banking market;

- developing the risk-based regulation of banks, introduction of the Basel II and Basel 2.5 standards concerning the market risk management;

- establishing the Eurasian Financial Stability Council subordinate to the Eurasian Economic Commission. The Eurasian Financial Stability Council would outline a body of rules and requirements with regard to governance of operations in the EAEU financial market. The competence of the Council may reasonable include a) articulating the conceptual rationale for maintaining the financial stability to boost an economic growth in the EAEU inter alia by establishing a supranational body governing the sector-based financial market; b) justifying initiatives for refining the regulatory and legislative framework for developing the EAEU common financial market; c) formulating respective guidelines for institutional organisms steering integration processes in the EAEU and national institutions regulating financial market sectors for macroeconomic stability. The Eurasian Financial Stability Market could be a successor of the existing the EEC Advisory Committee for Financial markets $^{10}$ with certain operational restrictions ${ }^{11}$;

- setting up a supranational supervisory body in the EAEU, which would regulate the common financial market and comprise three sectoral regulatory institutions, i.e. a) banking; b) securities; c) insurance ${ }^{12}$.

To regulate the EAEU Common Financial Market effectively and mitigate financial stability risks, the supranational supervisory body is supposed to have the following competence: 1) the right to make decisions binding for EAEU national regulators or directly financial institutions in certain areas of legislation and activities in financial markets; 2) the right to immediately supervise too-big-too-fail financial institutions that are very important for the economy and financial markets in the EAEU countries, and financial groups conducting financial activities in other EAEU countries.

The banking sector of the EAEU financial markets shall be congruent with standards of the Basel Committee on Banking Supervision (BCBS). As accepted internationally, regulatory and supervisory practices in banking of the EAEU countries evolve by actively integrating international standards set by the BCBS. The process rests on such fundamental documents as Core Principles for Effective Banking Supervision, International Convergence of Capital Measurement and

\footnotetext{
${ }^{10}$ Act on the Advisory Committee for Financial Markets. URL: http://www.eurasiancommission.org/ru/act/ (In Russ.)

${ }^{11}$ As per the Act on the Advisory Committee for Financial Markets established by the Resolution of the EEC Board of October 25, 2012, the Committee is intended to give advice to representatives of the EAEU member States and outline proposals for the EEC Board on such issues as formulation and enforcement of the harmonized policy for financial services (banking, insurance, securities, etc.) in the territories of the Parties; creation of conditions for expanding mutual trade in financial services and future formation of the uniform financial market; creation of favorable conditions for those entities operating in the territory of one of the Party to make investment in territories of other Parties. URL: http://www.eurasiancommission.org/ru/act/

${ }^{12}$ For reference: Based on the EU experience. The EU set up the European System of Financial Supervision (ESFS), which supervises the financial market and has three supervisory institutions, such as 1) the European Securities and Markets Authorities (ESMA), 2) the European Banking Authority (EBA); 3) the European Insurance and Occupational Pensions Authority (EIOPA).
} 
Capital Standards (Basel II) ${ }^{13}$, Global Regulatory Framework for More Resilient Banks and Banking Systems, International Framework for Liquidity Risk Measurement, Standards and Monitoring (Basel III) ${ }^{14}$.

Currently, the EAEU countries make their autonomous decisions on the adoption of the BCBS guidelines in accordance with their economic situation and financial system. If the EAEU countries take concerted efforts to implement the BCBS principles, they will manage to harmonize their regulatory regimes in banking successfully. It will enable them to forge uniform approaches to implementing international recommendation in accordance with their regional specifics and distinctions. Managing their systemic risks, the EAEU countries should cooperate in implementing the macroprudential regulatory framework of the Financial Stability Board and G-20 in relation to too-big-too-fail financial institutions in the EAEU countries.

\section{Conclusion}

The article provides principles, form and substance of the concept for developing the EAEU Common Financial Market. They are based on the model implying that financial markets will be integrated on an evolutionary and gradual basis. The EAEU countries should choose an appropriate algorithm and priorities, which best fit distinctions of their national economies and financial systems. They also should consider the financial and economic integration level to take adequate measures and decide on their preparedness to put them in practice [10]. Hence we would like to emphasize the importance of differentiating the sector, time and pace the countries can keep in developing the Common Financial Market and their successful integration.

The conventional integration process is so similar in the EAEU and EU, consistently evolutionizing from free trade zones and customs unions to the common internal market, common financial market and economic union. It is also worth mentioning that both regions opt for predominantly banking-based models of financial markets. Therefore, it would be reasonable to critically review and use positive aspects of the long-standing, ambiguous experience of the European Union in creating the European financial market. For example, financial institutions may be granted a EAEU financial services passport during the first stage, like it was done in the EU. It would enable them to operate throughout the EAEU. There should be a road map for developing, consolidating the banking sectors of the EAEU countries and harmonizing conditions for their common and joint work $^{15}$.

In the mean time, we suggest the EAEU should actively form the common markets for securities and insurance at the first stage. They shall follow harmonization principles and accomplish the process at the second stage.

It is the most critical point for the EAEU Common Financial Market to consolidate intergovernmental and supranational regulatory and supervisory authorities on an institutional basis.

As part of the proposed concept, we suggest establishing the Eurasian Council for Financial Stability subordinate to the EEC Advisory Committee for Financial markets and giving it a powerful mandate to regulate financial markets. We also believe it be reasonable to set up a supranational supervisory body in the EAEU, which is called to outline a body of rules and requirements to the governance of the EAEU common financial market and its actors' activities, and provide relevant recommendation to national and regional institutions for regulation and supervision.

\footnotetext{
${ }^{13}$ Basel Committee for Banking Supervision. International Convergence of Capital Measurement and Capital Standards: A Revised Framework. URL: http://www.cbr.ru/today/ms/bn/bz_1.pdf (In Russ.); https://www.bis.org/publ/bcbs118.htm

${ }^{14}$ Basel Committee for Banking Supervision. International Framework for Liquidity Risk Measurement, Standards and Monitoring. URL: https://www.cbr.ru/today/ms/bn/2.pdf (In Russ.); https://www.bis.org/publ/bcbs188.pdf
} 
Table 1

Trends in corporate lending in the EAEU countries, 2012-2016, million USD and percentage of GDP

\begin{tabular}{|c|c|c|c|c|c|c|c|c|c|c|}
\hline \multirow[t]{2}{*}{ Country } & \multicolumn{2}{|l|}{2012} & \multicolumn{2}{|l|}{2013} & \multicolumn{2}{|l|}{2014} & \multicolumn{2}{|l|}{2015} & \multicolumn{2}{|l|}{2016} \\
\hline & million USD & $\begin{array}{l}\% \text { of } \\
\text { GDP }\end{array}$ & million USD & $\begin{array}{l}\text { \% of } \\
\text { GDP }\end{array}$ & million USD & $\begin{array}{l}\% \text { of } \\
\text { GDP }\end{array}$ & $\begin{array}{l}\text { million } \\
\text { USD }\end{array}$ & $\begin{array}{l}\text { \% of } \\
\text { GDP }\end{array}$ & $\begin{array}{l}\text { million } \\
\text { USD }\end{array}$ & $\begin{array}{l}\% \text { of } \\
\text { GDP }\end{array}$ \\
\hline Armenia & - & - & - & - & - & - & - & - & - & - \\
\hline Belarus & 32,338 & 51 & 32,585 & 45 & 32,188 & 41 & 23,570 & 42.6 & 22,552 & 47.8 \\
\hline Kazakhstan & 38,430 & 18.5 & 39,892 & 16.9 & 44,589 & 20.1 & 32,817 & 17.8 & 22,248 & 16.6 \\
\hline Kyrgyzstan & 721 & 10.9 & 1,115 & 15.2 & 1,356 & 18.2 & 1,085 & 16.2 & 1,203 & 18.4 \\
\hline Russia & 973,770 & 45.2 & $1,138,421$ & 51 & $1,014,817$ & 49.4 & 564,391 & 42.4 & 531,870 & 41.4 \\
\hline EAEU $^{*}$ & $1,045,259$ & 42.8 & $1,212,014$ & 47.3 & $1,092,946$ & 45.4 & 621,862 & 38.2 & 577,875 & 38.9 \\
\hline
\end{tabular}

* Excluding Armenia

Source: Financial statistics of the Eurasian Economic Union. Moscow, Eurasian Economic Commission, 2017,

pp. 83-84.URL: http://www.eurasiancommission.org/ru/act/integr___makroec/dep_stat/finstat/_ocuments/finstat_2016.pdf (In Russ.);

EEU in figures. Cart Statistical Book. Moscow, Eurasian Economic Commission, 2017, p. 53.

URL: http://www.eurasiancommission.org/ru/act/integr_i_makroec/dep_stat/econstat/Documents/Brief_Statistics_Yearbook_2017.pdf (In Russ.)

\section{Table 2}

Trends in trading volume in the EAEU stock markets, 2012-2016, million USD and percentage of GDP

\begin{tabular}{|c|c|c|c|c|c|c|c|c|c|c|}
\hline \multirow[t]{2}{*}{ Country } & \multicolumn{2}{|l|}{2012} & \multicolumn{2}{|l|}{2013} & \multicolumn{2}{|l|}{2014} & \multicolumn{2}{|l|}{2015} & \multicolumn{2}{|l|}{2016} \\
\hline & million USD & $\begin{array}{l}\% \text { of } \\
\text { GDP }\end{array}$ & million USD & $\begin{array}{l}\% \text { of } \\
\text { GDP }\end{array}$ & million USD & $\begin{array}{l}\text { \% of } \\
\text { GDP }\end{array}$ & $\begin{array}{l}\text { million } \\
\text { USD }\end{array}$ & $\begin{array}{l}\text { \% of } \\
\text { GDP }\end{array}$ & $\begin{array}{l}\text { million } \\
\text { USD }\end{array}$ & $\begin{array}{l}\% \text { of } \\
\text { GDP }\end{array}$ \\
\hline Armenia & 12 & 0.11 & 41 & 0.37 & 152 & 1.31 & 29 & 0.26 & 114 & 1.08 \\
\hline Belarus & 5,081 & 7.77 & 5,554 & 7.43 & 6,470 & 8.24 & 6,152 & 11.12 & 4,814 & 10.21 \\
\hline Kazakhstan & 88,270 & 42.44 & 89,345 & 37.76 & 61,560 & 27.8 & 116,232 & 63.04 & 125,369 & 92.86 \\
\hline Kyrgyzstan & 25 & 0.38 & 34 & 0.46 & 30 & 0.4 & 62 & 0.93 & 143 & 2.18 \\
\hline Russia & 776,698 & 40.94 & 755,028 & 33.83 & 550,141 & 40.09 & 338,871 & 24.7 & 357,164 & 27.77 \\
\hline EAEU & 870,089 & 35.6 & 850,002 & 33.19 & 618,353 & 25.71 & 461,346 & 28.32 & 487,604 & 32.83 \\
\hline
\end{tabular}

Source : Financial statistics of the Eurasian Economic Union. Moscow, Eurasian Economic Commission, 2017, p. 86.

URL: http://www.eurasiancommission.org/ru/act/integr_i_makroec/dep_stat/finstat/Documents/finstat_2016.pdf (In Russ.);

EEU in figures. Cart Statistical Book. Moscow, Eurasian Economic Commission, 2017, p. 53.

URL: http://www.eurasiancommission.org/ru/act/integr_i_makroec/dep_stat/econstat/Documents/Brief_Statistics_Yearbook_2017.pdf (In Russ.) 


\section{Acknowledgments}

The article was supported by the Russian Foundation for Basic Research, grant № 17-02-00347.

\section{References}

1. Zvonova E.A., Ershov M.V., Kuznetsov A.V. et al. Reformirovanie mirovoi finansovoi arkhitektury i rossiiskii finansovyi rynok [World financial architecture reformation and the Russian financial market]. Moscow, Rusains Publ., 2016, 430 p. URL: https://doi.org/10.15216/978-5-4365-0570-1

2. Zvonova E.A., Pishchik V.Ya. [Assessment of factors securing economic growth and financial stability in the EEU Member States]. Finansy $i$ kredit = Finance and Credit, 2016, no. 18, pp. 2-18.

URL: https://cyberleninka.ru/article/n/otsenka-faktorov-obespecheniya-ekonomicheskogo-rosta-i-dostizheniyafinansovoy-stabilnosti-v-gosudarstvah-chlenah-evraziyskogo (In Russ.)

3. Navoi A.V. [On the role of banks in formation of trans-border capital flows]. Bankovskoe delo, 2012, no. 6, pp. 27-30. (In Russ.)

4. Guseva I.A., Kudinova M.M., Malyshev P.Yu. et al. Fondovye rynki stran SNG: sostoyanie i perspektivy integratsii: monografiya [Stock markets of the CIS countries: status and prospects of integration: a monograph]. Moscow, Rusains Publ., 2015, 192 p. URL: https://publications.hse.ru/mirror/pubs/share/direct/210916345

5. Pishchik V.Ya. [Building a capital markets union in the Euro Area: projection on the EAEU with the participation of Russia]. Ekonomika. Nalogi. Pravo = Economics, Taxes \& Law, 2016, no. 2, pp. 60-66.

URL: http://old.fa.ru/projects/enp/Documents/Экономика_налоги_право-2_2016.pdf (In Russ.)

6. Pishchik V.Ya., Zvonova E.A. [Institutional aspects of monetary and financial regulation in the Eurasian Economic Union]. Vestnik Finansovogo universiteta, 2014, no. 6, pp. 92-100. (In Russ.)

7. Grishina O.A., Zvonova E.A. Regulirovanie mirovogo finansovogo rynka: teoriya, praktika, instrumenty: monografiya [Regulation of the world financial market: theory, practice, tools: a monograph]. Moscow, Finansy i Statistika Publ., 2007, 382 p.

8. Bagdasaryan A.M. [Analysis of key indicators of the regulated securities market in the Republic of Armenia]. Voprosy upravleniya = Management Issues, 2013, no. 4, pp. 89-94.

URL: http://vestnik.uapa.ru/ru/issue/2013/04/14/ (In Russ.)

9. Pishchik V.Ya. [Trends in the development of the European economic and monetary Union]. Mezhdunarodnaya ekonomika = The World Economics, 2013, no. 2, pp. 28-35. (In Russ.)

10. De Grauwe P. Crisis in the Eurozone and How to Deal with It. CEPS Policy Brief, 2010, February 15, no. 204. URL: https://papers.ssrn.com/sol3/Papers.cfm?abstract_id=1604453

\section{Conflict-of-interest notification}

We, the authors of this article, bindingly and explicitly declare of the partial and total lack of actual or potential conflict of interest with any other third party whatsoever, which may arise as a result of the publication of this article. This statement relates to the study, data collection and interpretation, writing and preparation of the article, and the decision to submit the manuscript for publication. 